\title{
Ekstruzja ortodontyczna zęba po urazie z wykorzystaniem aparatu zdejmowanego (aparato-protezy) - opis przypadku
}

\author{
Orthodontic extrusion of a tooth after trauma using removable appliance - case study \\ ${ }^{1}$ Katedra i Klinika Ortopedii Szczękowej i Ortodoncji, Uniwersytet Medyczny im. Karola Marcinkowskiego w Poznaniu \\ Chair and Department of Maxillofacial Orthopaedics and Orthodontics, Poznan University of Medical Sciences \\ 2Zakład Anatomii Prawidłowej, Katedra i Zakład Biomateriałów i Stomatologii Doświadczalnej, \\ Uniwersytet Medyczny im. Karola Marcinkowskiego w Poznaniu \\ Department of Normal Anatomy, Chair and Department of Biomaterials and Experimental Dentistry, \\ Poznan University of Medical Sciences
}

DOI: http://dx.doi.org/10.20883/df.2020.19

\section{STRESZCZENIE}

Praca zawiera opis przypadku podjęcia próby ekstruzji ortodontycznej zęba po urazie z wykorzystaniem aparatorotezy. Po 6 miesiącach leczenia nie uzyskano postępu. Na niepowodzenie mogło mieć wpływ wiele czynników: późne rozpoczęcie terapii, brak współpracy z aparatem zdejmowanym, ankyloza zęba po urazie. Złotym standardem w wykonywaniu ekstruzji nadal pozostaje zastosowanie aparatu stałego z ewentualnym zastosowaniem kortykotomii jako wspomaganie chirurgiczne leczenia ortodontycznego.

Słowa kluczowe: aparat zdejmowany, ekstruzja ortodontyczna, uraz, terapia ortodontyczna.

\section{ABSTRACT}

Publication presents case study describing an attempt of orthodontic extrusion of a tooth after trauma using removable appliance. After 6 months of treatment there was no improvement. The reason of lack of progress is composed of many factors such as: late start of therapy, lack of cooperation with removable appliance, ankylosis of the tooth after trauma. The use of fixed braces with the possible use of corticotomy as a surgical support still remains the gold standard in performing orthodontic extrusion.

Keywords: removable appliance, orthodontic extrusion, trauma, orthodontic treatment.

\section{Wprowadzenie}

Ekstruzja ortodontyczna jest techniką szeroko wykorzystywaną nie tylko w leczeniu ortodontycznym wad zgryzu, ale także w przypadku leczenia pacjenta wymagającego leczenia interdyscyplinarnego [1, 2]. Technika kontrolowanej ekstruzji ortodontycznej zęba w przypadku urazów, np. złamań poniżej przyczepu dziąsłowego, pozwala na uniknięcie zabiegów periodontologicznych wydłużenia korony klinicznej lub ekstrakcji zęba. Metody uzyskania kontrolowanej ekstruzji ortodontycznej można podzielić na metody z wykorzystaniem aparatów zdejmowanych [3-5] lub aparatów stałych, w tym z zastosowaniem zakotwienia szkieletowego na miniimplantach ortodontycznych [6]. W pi- śmiennictwie opisanych jest wiele zalet ekstruzji z wykorzystaniem aparatów stałych, jak precyzja i ciągłość działania stosowanej siły. Ich ograniczenia są spójne z przeciwwskazaniami ogólnymi do stosowania aparatów stałych, jak na przykład zła higiena jamy ustnej [7]. Do zalet stosowania aparatów zdejmowanych należy z pewnością łatwość w oczyszczaniu zębów oraz niższy koszt [8]. Wybór metody jest indywidualnie dobrany do sytuacji klinicznej. Celem pracy jest przedstawienie możliwości ekstruzji ortodontycznej zęba z wykorzystaniem aparato-protezy jako przygotowanie do wielospecjalistycznego leczenia stomatologicznego. 


\section{Materiał i metody}

Dokonano opisu przypadku leczonego w Poradni Katedry i Kliniki Ortopedii Szczękowej i Ortodoncji Uniwersytetu Medycznego w Poznaniu przez okres 6 miesięcy z wykorzystaniem aparato-protezy.

\section{Opis przypadku}

Pacjent lat 37 zgłosił się do Poradni Ortopedii Szczękowej i Ortodoncji celem konsultacji i oceny możliwości wykonania ekstruzji ortodontycznej zęba 13. Z wywiadu wiadomo, że 4 miesiące wcześniej w wyniku upadku z wysokości kilku metrów i w skutek uderzenia o ziemię doszło do złamania żuchwy, utraty zębów 11, 12, wtłoczenia zęba 13 w głąb tkanek oraz porażenia nerwów w zakresie czucia i funkcji mięśni mimicznych twarzy. Po urazie pacjent został zaopatrzony w klinice chirurgii szczękowo-twarzowej. Wykonano osteosyntezę płytkową odłamów złamania żuchwy (Ryciny 1 i 2). Reedukacja nerwowo-mięśniowa wspierana jest zabiegami fizjoterapeutycznymi. Lekarz prowadzący przedstawił pacjentowi plan leczenia obejmujący terapię i rehabilitację narządu żucia, na co pacjent wyraził zgodę. Ząb 13 został wstępnie zakwalifikowany przez lekarza prowadzącego jako filar do przyszłej odbudowy protetycznej.

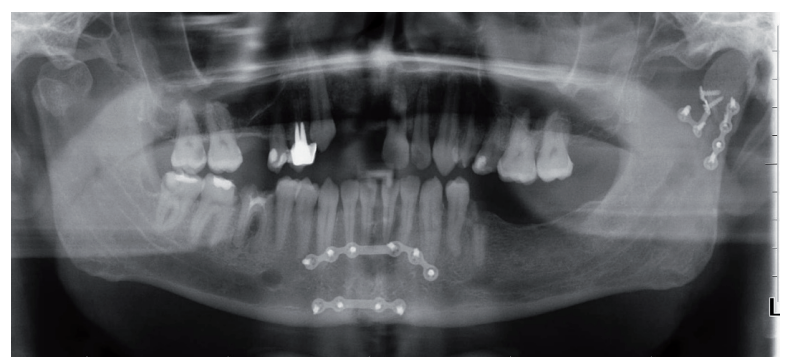

Rycina 1. OPG pacjenta po zaopatrzeniu chirurgicznym, przed rozpoczęciem ekstruzji zęba 13

Figure 1. OPG after surgery, before extrusion of 13

W opisie OPG stwierdzono stan po leczeniu operacyjnym złamań żuchwy. Widoczne płytki osteosyntezy w okolicy brzegu dolnego żuchwy w rzucie bródki, widoczna szczelina złamania przechodząca przez brzeg dolny żuchwy biegnąca w kierunku korzenia zęba 42 . Widoczna płytka założona na wysokości wierzchołków zębów 33 do 44 oraz płytka zespalająca odłamy złamanego wyrostka stawowego po stronie lewej. Po stronie prawej widoczne wyraźne skrócenie wyrostka stawowego sugerujące przebyte złamanie wyrostka po tej stronie z możliwym przemieszczeniem odłamu. Ząb 13 wtłoczony w głąb tkanek. Zmiany okołowierzchołkowe zębów 34 i 46. Pozostały korzeń zęba 35.
Lewa zatoka brak prawidłowego upowietrznienia

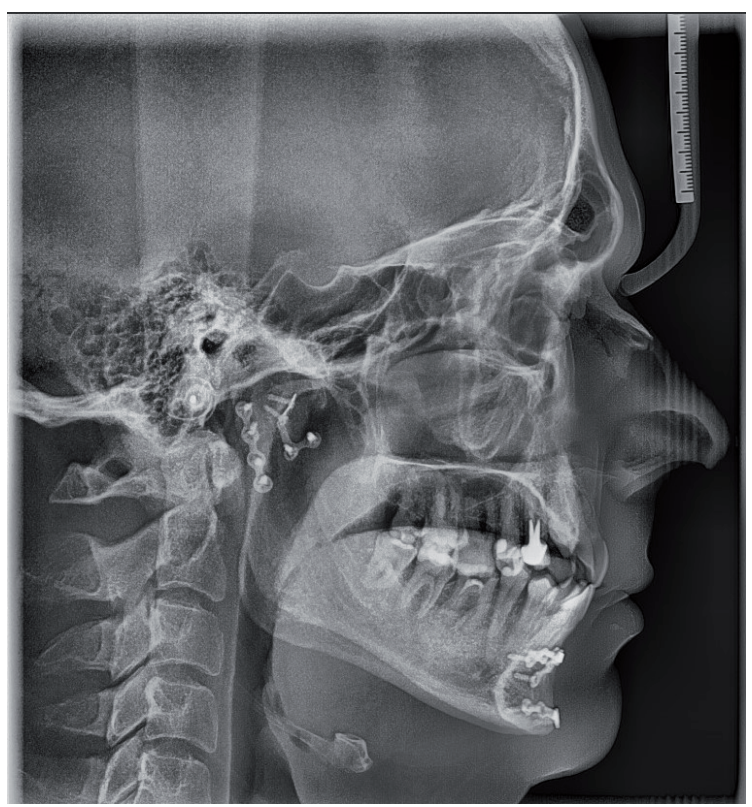

Rycina 2. RTG cefalometryczne pacjenta po zaopatrzeniu chirurgicznym, przed rozpoczęciem ekstruzji zęba 13

Figure 2. Cephalometric x-ray after surgery, before extrusion of 13

Mając na uwadze stan ogólny pacjenta, niski poziom higieny jamy ustnej, ograniczone odwiedzenie żuchwy uniemożliwiające precyzyjne przyklejenie aparatu stałego oraz względy ekonomiczne, podjęto decyzję o podjęciu próby ekstruzji ortodontycznej z wykorzystaniem aparato-protezy z uzupełnieniem braku zębów 11, 12.

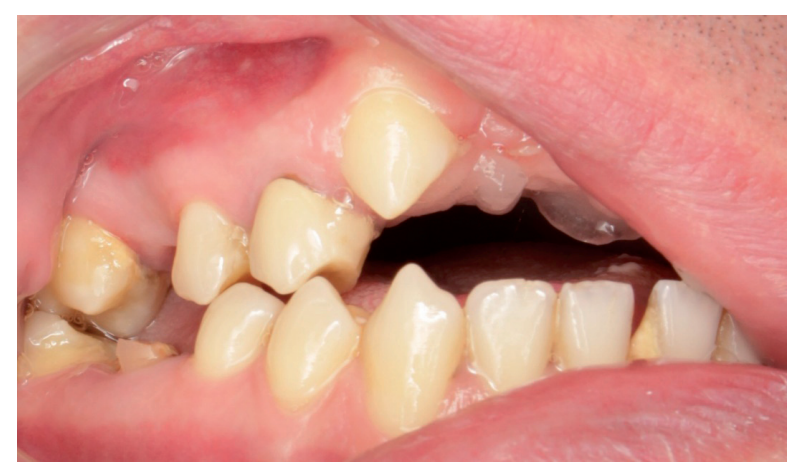

Rycina 3. Dokumentacja fotograficzna przed rozpoczęciem ekstruzji zęba 13

Figure 3. Photographic documentation before extrusion of 13

Wykonano płytkę Schwarza z klamrami Adamsa na pierwsze zęby trzonowe oraz klamrą grotową w okolicy zębów 14, 15. W aparacie uzupełniono brakujące zęby 11, 21. Oprócz tego zastosowano dodatkowy element druciany wychodzący z płyty aparatu na wysokości zęba 13 z okrągłym oczkiem równoległym do płaszczyzny zgryzu na poziomie brzegu siecznego zęba 12 i guzka policzkowego 
14 jako miejsce przyczepienia wyciągu elastycznego. Na ząb 13, przydziąsłowo, przyklejono guziczek jako drugie miejsce zaczepienia wyciągu. Zalecono całodobowe użytkowanie aparato-protezy. Kontrole odbywały się co 6-8 tygodni. Początkowo zalecono wyciągi 1/8" heavy, następnie $1 / 4$ " heavy, a końcowo podwójny 1/8" heavy. Ze względu na sytuację epidemiologiczną związaną z wirusem SARS-Cov2 i brak możliwości regularnych kontroli, okres aktywnego leczenia uległ wydłużeniu i wyniósł 6 miesięcy. W trakcie wizyt kontrolnych wykonywano dokumentację fotograficzną oraz dokonywano pomiaru długości korony klinicznej.

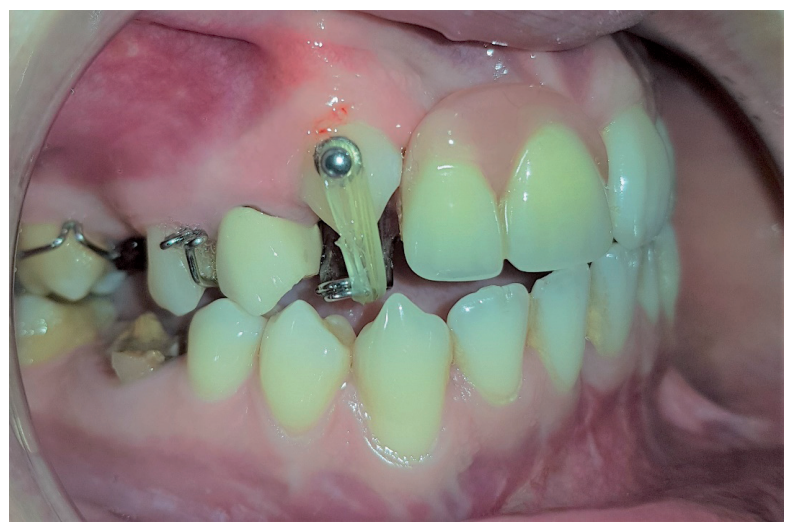

Rycina 4. Aparato-proteza z podłączeniem wyciągu do guziczka na zębie 13

Figure 4. Removable appliance connected with elastic to the tooth 13

Po analizie długości korony klinicznej przed leczeniem i po okresie aktywnego leczenia nie odnotowano wydłużenia korony klinicznej.

Przekazano informację zwrotną do lekarza prowadzącego. Po konsultacji z chirurgiem należącym do zespołu interdyscyplinarnego zaproponowano pacjentowi możliwość wykonania kortykotomii celem wspomożenia efektywności ekstruzji. Kontynuacja leczenia z chirurgicznym wspomaganiem ekstruzji wymaga zmiany aparatu zdejmowanego na aparat stały cienkołukowy w szczęce.

\section{Dyskusja}

Na niepowodzenie mogło mieć wpływ wiele czynników. Należy do nich zaliczyć późne rozpoczęcie terapii, możliwy brak współpracy w zakresie całodobowego noszenia aparatu zdejmowanego, ankyloza zęba po urazie.

Aluchna i wsp. podają, że w przypadku urazu zęba ekstruzję ortodontyczną należy rozpocząć w ciągu 3 tygodni. Opisywano także pojedynczy przypadek udanej ekstruzji zęba rozpoczętej po 9 tygodniach [7].
Współpraca pacjenta podczas leczenia aparatem zdejmowanym jest kluczowym elementem decydującym o uzyskanym efekcie lub jego braku [9]. Jest to prawdopodobna przyczyna wielu kontrowersji na temat skuteczności stosowania aparatów zdejmowanych [10].

Mając na uwadze brak efektów leczenia po okresie 6 miesięcy, przy założeniu doskonałej współpracy pacjenta, istnieje prawdopodobieństwo występowania pourazowej ankylozy zęba. Rahnama i wsp. opisują, że w leczeniu ortodontycznym, przy obecności zębów ankylotycznych, kortykotomia jest zabiegiem z wyboru [11]. U pacjenta prezentowanego wskazane byłoby wykonie CBCT [12].

\section{Podsumowanie}

W piśmiennictwie opisane są przypadki ekstruzji ortodontycznej z wykorzystaniem aparatów zdejmowanych zakończone sukcesem.

\section{Oświadczenia}

\section{Oświadczenie dotyczące konfliktu interesów}

Autorzy deklarują brak konfliktu interesów w autorstwie oraz publikacji pracy.

\section{Źródła finansowania}

Autorzy deklarują brak źródeł finansowania.

\section{Piśmiennictwo}

[1] Szarmach I, Kalinowska M, Szarmach J, Sierpińska T, Gołębiewska M. Ekstruzja ortodontyczna metodą z wyboru w przypadku poddziąsłowego złamania korzenia zęba - wieloletnie obserwacje. Czas. Stomatol., 61,12,875-881,2008.

[2] Reyes E, Barrow S, McLeod DE. Crown lengthening with removable orthodontics: a combined approach for ideal esthetics. Gen Dent. Sep-Oct;59(5):362-6, 2011.

[3] Mohammad Z, Penmetcha S, Bagalkotkar A, Namineni S. A Novel Approach to extrude Subgingivally Fractured Tooth using Customized Removable Appliance. Int J Clin Pediatr Dent. Jan-Feb;11(1):53-57, 2018.

[4] Orton HS, Garvey MT, Pearson MH. Extrusion of the ectopic maxillary canine using a lower removable appliance. Am J Orthod Dentofacial Orthop. Apr;107(4):349-59,1995.

[5] Mathai JK. Orthodontic management of maxillary impacted canine with removable appliance. A case report. J Indian Dent Assoc. Feb;55(2):75-7,1983.

[6] Greco M, Derton N. Orthodontic extrusion for a preprosthetic approach: a bracketless mini-implantbased mechanics. Orthodontics (Chic.). 13(1):210-5, 2012.

[7] Aluchna A, Garbas K, Stasiak M. Kontrolowana ekstruzja ortodontyczna jako element leczenia interdyscyplinarnego - przegląd piśmiennictwa. Ortodoncja w praktyce 4:32,2017. 
[8] Darby LJ, Garvey TM, O'Connell AC. Orthodontic extrusion in the transitional dentition: a simple technique. Pediatr Dent. Nov-Dec;31(7):520-2,2009.

[9] Schott TC, Göz G. Young patients' attitudes toward removable appliance wear times, wear-time instructions and electronic wear-time measurements-results of a questionnaire study. J Orofac Orthop. Mar;71(2):108-16,2010.

[10] Sarul M, Kawala B, Kozanecka A, Łyczek J, Antoszewska-Smith J. Objectively measured compliance during early orthodontic treatment: Do treatment needs have an impact? Adv Clin Exp Med. Jan-Feb;26(1):83-87,2017.

[11] Rahnama M, Czajkowski L, Smyl-Golianek M, Kurzępa A, Gałuszka J. Kortykotomia jako zabieg z wyboru w leczeniu ortodontycznym przy obecności zębów ankilotycznych - opis przypadku, Magazyn Stomatologiczny 6/2014.
[12] Palomo L, Palomo JM. Cone beam CT for diagnosis and treatment planning in trauma cases. Dent Clin North Am. Oct;53(4):717-27,2009.

Zaakceptowano do edycji: 2020-10-06 Zaakceptowano do publikacji: 2020-10-06

Adres do korespondencji: Marta Dyszkiewicz-Konwińska Katedra i Zakład Biomateriałów i Stomatologii Doświadczalnej, Uniwersytet Medyczny im. Karola Marcinkowskiego w Poznaniu 